\title{
Reproductive biology of Hyphessobrycon eques (Characiformes: Characidae) in Southern Pantanal, Brazil
}

\author{
C. A. Santana ${ }^{a}$, K. K. Tondato Thd Y. R. Súarez $^{a}$ \\ aPrograma de Pós-graduação em Recursos Naturais - PGRN, Laboratório de Ecologia, Centro de Estudos em Recursos \\ Naturais - CERNA, Universidade Estadual de Mato Grosso do Sul - UEMS, Rod. Dourados-Itahum, Km 12, \\ CEP 79804-970, Dourados, MS, Brasil

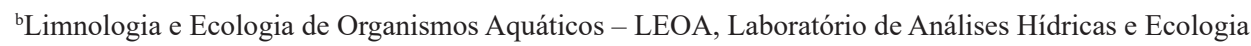 \\ Aplicada, Departamento de Ciências Biológicas, Instituto de Ciências Exatas e Naturais, Universidade Federal de \\ Mato Grosso - UFMT, Rod. Rondonópolis, Guiratinga Km 06, CEP 78735-901, Rondonópolis, MT, Brasil \\ *e-mail: santana.avila@gmail.com
}

Received: February 23, 2017 - Accepted: August 19, 2017 - Distributed: February 28, 2019

(With 9 figures)

\begin{abstract}
Population and reproductive aspects allow the knowledge and understanding of population dynamics and the influence of environmental factors, in addition to ensure the success of a species continuity. Thus, the aim of this study was to analyze population and reproductive traits of the species Hyphessobrycon eques in southern Pantanal, Brazil. Monthly samplings were conducted from February/2009 to January/2011, with 617 individuals analyzed, being 365 females and 262 males. A similar form of distribution in length and weight between the sexes was observed. There was no significant variation in sex ratio over time, with higher proportion of females during the entire sampled period. Both sexes presented a angular coefficient of Weight/Length (b) relationship greater than 3, with speed of increase in weight greater than in length. For females, a long reproductive period was observed, with greater reproductive intensity from January through June. No significant correlation was observed between the Gonadosomatic Index (GSI) and the average temperature, rainfall and river level, despite the fact that reproductive activity occurs in autumn/winter, when there are favorable conditions due to flooding. The size at first maturation $\left(\mathrm{L}_{50}\right)$ was $20.2 \mathrm{~mm}$, with confidence interval varying from 19.7 through $20.7 \mathrm{~mm}$. The average fecundity was 191.9 oocytes/females and was significantly related to the standard length and total weight (g), demonstrating a relation with energy accumulation to invest in reproduction. The long reproductive period, intensified by partial spawning, higher proportion of females and low $\mathrm{L}_{50}$, show that the species has strategies necessary for survival and rapid population growth, common in small species characterized as $r$-strategists.
\end{abstract}

Keywords: sex ratio, fish, reproductive biology, life history, Paraguay River.

\section{Biologia Reprodutiva de Hyphessobrycon eques (Characiformes: Characidae) no Pantanal Sul, Brasil}

\begin{abstract}
Resumo
Os aspectos populacionais e reprodutivos permitem o conhecimento e a compreensão da dinâmica populacional e da influência de fatores ambientais, assegurando o sucesso da continuidade de uma espécie. Desta forma, o presente trabalho teve como objetivo analisar os traços populacionais e reprodutivos da espécie Hyphessobrycon eques no Sul do Pantanal, Brasil. Foram realizadas amostragens mensais de Fevereiro/2009 a Janeiro/2011, com um total de 617 indivíduos analisados, sendo 365 fêmeas e 262 machos. Foi observada que a distribuição foi similar em comprimento e peso entre os sexos. Não ocorreu variação significativa na proporção sexual ao longo do tempo, com maior proporção de fêmeas durante todo período amostrado. Ambos os sexos apresentaram um coeficiente angular da relação Peso/Comprimento (b) maior que 3, com velocidade do incremento em peso maior do que em comprimento. Para as fêmeas, foi observado um período reprodutivo longo, com maior intensidade reprodutiva de Janeiro e Junho. Não foi observada correlação significativa entre o Índice Gonadossomático (IGS) e a temperatura média, pluviosidade e nível do rio, apesar de ocorrer atividade reprodutiva no outono/inverno, período que há condições favoráveis decorrentes da inundação. $\mathrm{O}$ tamanho de primeira maturação $\left(\mathrm{L}_{50}\right)$ foi de 20,2 mm, com intervalo de confiança variando entre 19,7 e 20,7 mm. A fecundidade média foi de 191,9 ovócitos/fêmea e esteve relacionada significativamente ao comprimento padrão e peso total (g), demonstrando uma relação com acúmulo de energia para investir na reprodução. O período reprodutivo longo, intensificado pela desova parcelada, maior proporção de fêmeas e baixo $\mathrm{L}_{50}$, mostram que a espécie possui estratégias necessárias para sobrevivência e rápido crescimento da população, comum em espécies de pequeno porte caracterizadas como r-estrategistas.
\end{abstract}

Palavras-chave: proporção sexual, peixe, biologia reprodutiva, história de vida, Rio Paraguai. 


\section{Introduction}

It is widely reported to fish, high plasticity in life history traits such as reproduction, growth and mortality in response to environmental variations. This plasticity is capable of providing knowledge about the behavior of a particular species (Tondato et al., 2012, 2014). In Neotropical region, studies that quantify life history traits of fishes are concentrated mainly in the medium and large-sized species, which present commercial interest and are targets of fishing (Mateus and Penha, 2007; Arantes et al., 2011; Paschoalini et al., 2013). Recently, however, studies have analyzed population and reproductive traits of small species in different environments (Cunha et al., 2007; Tondato et al., 2014; Normando et al., 2014; Almeida-Silva and Mazzoni, 2014; Súarez et al., 2017), showing a high phenotypic plasticity in response to spatio-temporal variations (Mérona et al., 2009; Olden and Kennard, 2010).

Reproduction is one of the most important aspects of the biology of a species, since it provides information traits such as fertility, sex ratio, size at first maturation and structure in length, which exhibit variations in response to environmental conditions being able to diagnose the different strategies (Suzuki et al., 2005; Rêgo et al., 2008; Olden and Kennard, 2010; Lourenço et al., 2012; Souza et al., 2014).

These traits have direct and indirect effects on reproduction and fitness of fish, since they define the individual's ability to produce sufficient offspring, allowing the maintenance of viable populations and ensuring the species success (Winemiller, 2003; Mérona et al., 2009). Thus, the knowledge of population and reproductive aspects in addition to allow the understanding of the population dynamics and the influence of abiotic and biotic factors, such as temperature, predation, competition and hydroperiod (Wootton, 1999), also contributes with information regarding the establishment of rules for management and conservation of species (Mônaco et al., 2014).

Among the environmental factors, flood regime is the most documented as one of the determining factors in fish ecology in floodplains of temperate and tropical regions (Agostinho et al., 2003; Bailly et al., 2008; Zeug and Winemiller, 2008). In Brazilian Pantanal floodplain, in response to spatial differences in environmental conditions, small fish species can exhibit wide range of reproductive strategies, but reproduction is seasonal and most fish species spawn at the start of the flood due to greater availability of food and shelter for the larvae and juveniles (Agostinho et al., 2004; Bailly et al., 2008).

The genus Hyphessobrycon Durbin is composed of 136 species belonging to the order Characiformes, which is a dominant group among small fish of freshwater in South America, comprising herbivorous forms, omnivorous, iliophagous, carnivorous, some of which are very specialized (Dagosta et al., 2016), and are considered opportunists. The term opportunist was associated with small fish species that usually have rapid development with early maturation, high fecundity and low juvenile survival (Winemiller, 1989). Due to this characteristic, they show a wide variation in life history traits being distributed in several environmental conditions (Froese and Pauly, 2011).
The species Hyphessobrycon eques (Steindachner, 1882) is originally found in the Amazon, Guaporé and Paraguay basins, considered an ornamental species (Pelicice and Agostinho, 2006), popularly known as "Mato Grosso" and widely found in aquarium stores in several regions of Brazil, even with scarce information about its ecology. Currently, H. eques is also found in the upper Paraná River basin and rivers of eastern Brazil due to its introduction (Buckup et al., 2007).

Knowing that life history traits present plasticity, varying with local environmental conditions, to maximize reproductive success, the objective of this study was to assess the reproductive strategy of Mato Grosso (H. eques) through analyzes of several reproductive tactics and understanding the factors that influence the maintenance of viable population over time. Thus, the reproductive strategy was evaluated with the following objectives: (i) characterize the population structure regarding length/weight relationships length and total weight distribution and sex-ratio; (ii) determine the reproductive period considering gonadal development stages and gonadosomatic index (GSI); (iii) verify the relationship between GSI and rainfall, water temperature and river level; (iv) estimate the size at first maturation $\left(\mathrm{L}_{50}\right) ;(\mathrm{v})$ determine their fecundity and their relationships with standard length and total weight and (vi) determine the type of spawning, by the frequency distribution of oocytes diameter.

\section{Material and Methods}

\subsection{Study area}

Pantanal is one of the largest floodplains in the world, located in the central part of South America. The main river in Pantanal is Paraguay with an extension of $2,621 \mathrm{~km}$ from its headwaters in Serra de Araporé to its mouth in Paraná River. Rainfall varies from 800 to $1400 \mathrm{~mm} /$ year, with $80 \%$ between November and March (Fantin-Cruz et al., 2011). Pantanal of Porto Murtinho is a sub-region of Pantanal, located along the Paraguay River, whose North and South boundaries are Nabileque and Apa rivers, respectively (Silva and Abdon, 1998). The peak of the flood in this region occurs between June and August when the rainfall is low and the level of Paraguay River reaches almost six meters. Due to its sinuous course, Paraguay River in the region analyzed also features some oxbow lakes formed by abandoned meanders (Figure 1), which are directly linked to the river and thus heavily influenced by its seasonality.

\subsection{Data collection}

Monthly samplings were carried out on aquatic macrophyte beds in Paraguay River, Amonguijá River and oxbow lakes of Paraguay River in Porto Murtinho, Brazil, from February 2009 to January 2011. Samples were made with seine nets $(1.5 \times 5 \mathrm{~m})$ and a sieve $(0.8 \times 1.2 \mathrm{~m})$ with approximately $2 \mathrm{~mm}$ mesh. During the two years of sampling, 109 sample units (sites) were obtained, aiming at the capture of several species of interest, including H. eques, with non-standardized sampling effort (Figure 1).

In the field, fish were anesthetized with eugenol, fixed in $10 \%$ formalin and labeled for subsequent analysis in 


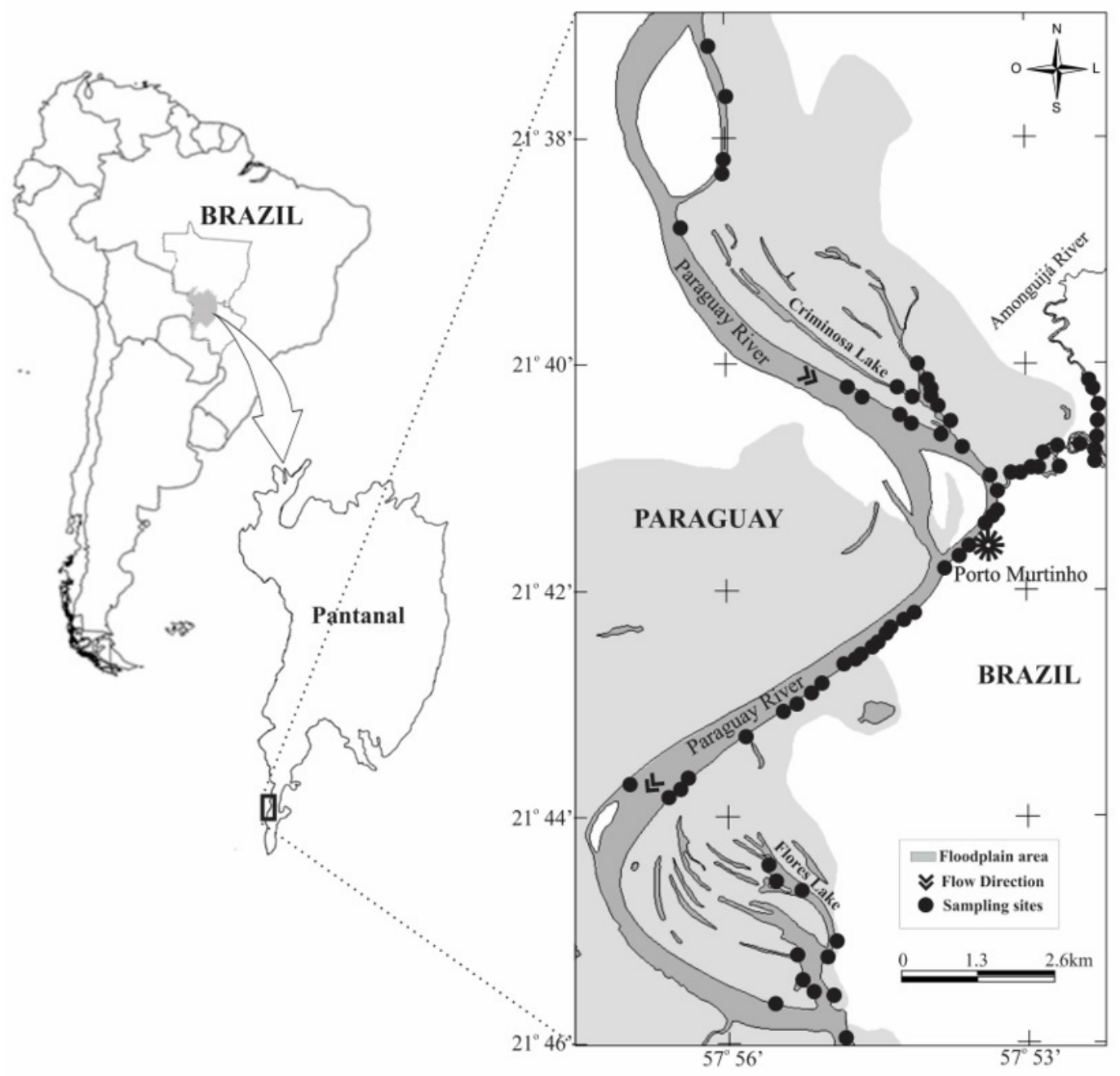

Figure 1. Location of the study area (109 sample units), in the sub region of the Pantanal of Porto Murtinho from February 2009 to January 2011.

laboratory where they were transferred to $70 \%$ alcohol. Identification was carried out in laboratory and voucher specimens (\#11169) were deposited in the fish collection of the Zoology Department, Universidade Federal do Rio Grande do Sul, Porto Alegre, Brazil. Subsequently, approximately 30 fish per month were analyzed, but it was not possible to evaluate 30 individuals in every 24 months so the data of equivalent months of both years have been integrated.

From each specimen the following biometric data were obtained: total weight $(\mathrm{g})$; standard length $(\mathrm{mm})$; sex; gonadal maturation stages of females (immature, maturing, mature and semi-exhausted) and weight of gonads (g) (Vazzoler, 1996). Absolute fecundity was estimated by counting all the vitellogenic oocytes present in ovaries of 50 previously selected females with high gonadosomatic index (GSI) values and classified as mature,. GSI was estimated as weight of gonads/total weight*100, as suggested by Adebisi (1987) and relative fecundity was determined by the number of oocytes per milligram of total weight of the female.

During collections, the following data were obtained: water temperature at sampled points, as well as river level and monthly total rainfall data. The values for river level were provided by Brazilian National Water Agency (Agência Nacional das Águas - ANA) from the 67100000 station in Porto Murtinho Municipality and rainfall data were provided by Brazilian National Institute of Meteorology (Instituto Nacional de Meteorologia-INMET) and obtained by the automatic station of Porto Murtinho.

\subsection{Data analysis}

The structure in length was analyzed by visual inspection of the frequency distributions of standard length of the population between sexes, in addition to Kolmogorov 
Smirnov test to compare the form of length and weight distribution between sexes, once the large amount of data and lack of standardization in number of males and females could result in type I error. Thus, initially, the frequency of individuals of both sexes was distributed in length classes, individuals grouped every $3 \mathrm{~mm}$, and the weight in classes of $0.1 \mathrm{~g}$, in order to standardize the data for analysis and graphical representation.

The sex ratio was determined by monthly distributions of males and females throughout the period of study. In order to calculate the overall and over the months sex ratio it was used the Chi-square test $\left(\chi^{2}\right)$ with Yates correction.

The length/weight relationship (LWR) was obtained for each sex by non-linear regression analysis, in which weight and length data were directly adjusted by the function: Total weight $=\mathrm{a} *$ Standard length ${ }^{\mathrm{b}}$, being: $\mathrm{a}=$ constant and $\mathrm{b}=$ angular coefficient of growth; with $\mathrm{b}=3$ isometric, $\mathrm{b}<3$ negative allometric and $\mathrm{b}>3$ positive allometric (Jones et al., 1999). Growth rate was determined by analysis of the confidence interval of the allometric coefficient (b).

After calculation of the gonadosomatic index, its seasonal variation was used to define the reproductive intensity, and the existence of significant variation in GSI over the months was verified by Kruskal-Wallis test. Thus, the reproductive period determination resulted from the monthly variation in GSI and frequency of gonadal maturation stages.

The average values of females GSI obtained each month were used for analysis of the influence of variation in rainfall, average temperature and historical level of the river on reproductive dynamics by Spearman's correlation.

The size at first maturation was estimated using a logistic regression, according to the method proposed by Roa et al. (1999), in which individuals that appeared to be immature were considered non-reproductive $(0)$ and those that showed gonadal maturation stage of "maturing" and beyond were classified as reproductive animals.

The possible relations between absolute fecundity and standard length $(\mathrm{mm})$ and total weight $(\mathrm{g})$ were determined using Spearman's correlation and the type of spawning was determined using the same gonads selected for fecundity analysis. A sub-sample was obtained from each gonad selected, and the largest diameter of 150 random oocytes was obtained using a stereomicroscope with a graduated ocular (mm) (Vazzoler, 1996). The values obtained were grouped in classes of oocyte diameter, and the distribution of the frequencies of these classes was determined to establish, by visual inspection, how the females release mature oocytes during a reproductive period, seeing if spawning is total or partial (Vazzoler, 1996).

\section{Results}

We analyzed a total of 617 individuals, 365 females and 252 males. The standard length of females ranged from 14.4 to $30.58 \mathrm{~mm}$ (median $=23.3 \mathrm{~mm}$ ) and for males it ranged from 13.4 to $30.1 \mathrm{~mm}$ (median $=23.0 \mathrm{~mm}$ ) (Figure 2a). The total weight of females ranged from 0.04 to $0.66 \mathrm{~g}$ (median $=0.26 \mathrm{~g}$ ) and of males from 0.04 to $0.57 \mathrm{~g}$ (median $=0.24 \mathrm{~g}$ ) (Figure 2b). No significant variation was observed in the form of distribution of standard length and total weight between females and males, noting only the highest frequency of females in the largest weights, in addition to reaching maximum length and weight in relation to males (Figure 2).

The sex ratio differed significantly from 1:1 $\left(\chi^{2}=20.70\right.$; $\mathrm{gl}=1 ; \mathrm{p}<0.001)$, with 1.45 females for each male and there was not significant variation in sex ratio throughout the years with higher proportion of females throughout the sampling cycle $\left(\chi^{2}=18.39 ; \mathrm{gl}=11 ; \mathrm{p}=0.07\right)$ (Figure 3 ).
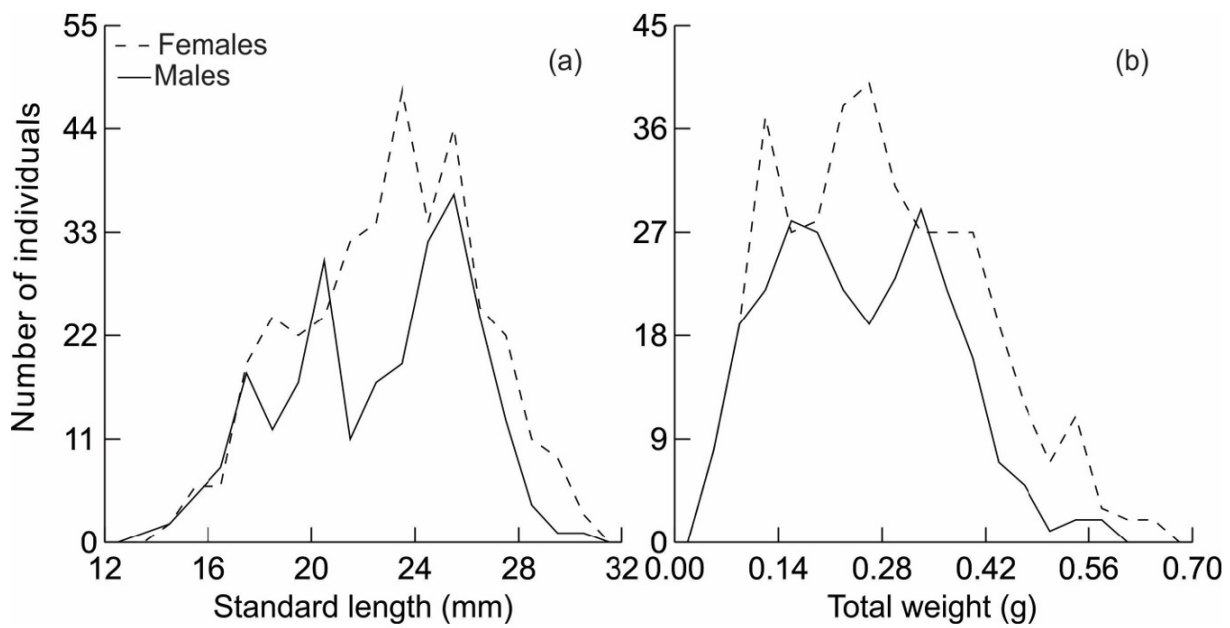

Figure 2. Density plot of relative frequency for standard length (a) and total weight (b) for H. eques females and males in Paraguay River from February 2009 to January 2011. 
For females it was possible to accurately predict $r^{2}=94.7 \%$ the weight of individuals using the standard length as predictor, and the generated model for females was Total weight $=0.00001075 *$ Standard length ${ }^{3.23}$, with the confidence interval estimated for the coefficient of allometry (b) varying between 3.14-3.32 ( $\alpha=0.05)$ (Figure 4). For males it was possible to predict with accuracy $r^{2}=95.7 \%$ the weight of individuals and the model generated was Total weight $=0.00001142 *$ Standard length ${ }^{3.18}$, with the confidence interval estimated for the coefficient (b) varying between 3.08-3.29 ( $\alpha=0.05$ ) (Figure 4). Growth of females and males can be considered positively

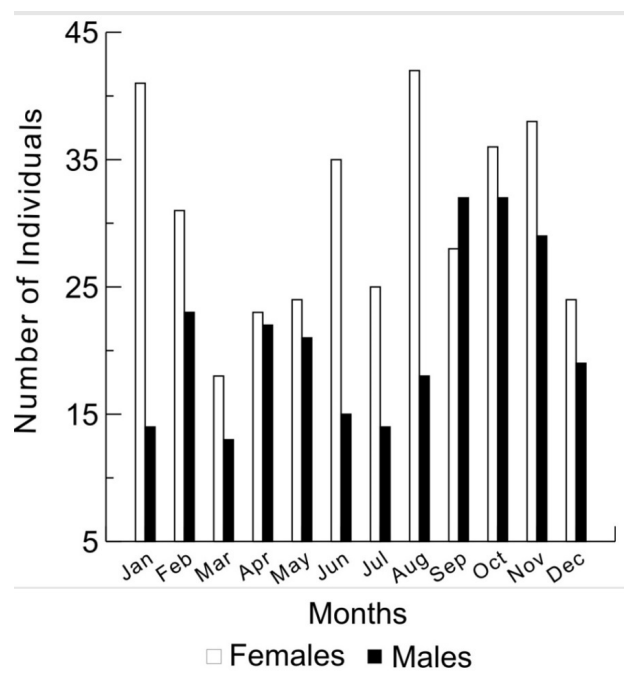

Figure 3. Temporal variation in number of $H$. eques females and males in Paraguay River from February/2009 to January/2011.

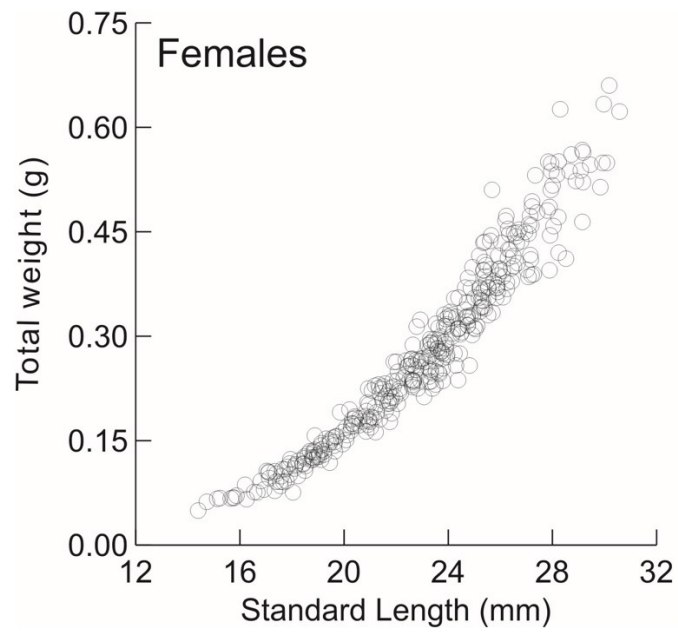

allometric, because the coefficient of allometry "b" adjusted by non-linear regression was statistically greater than 3 , indicating that the speed of increase in weight is greater than in length (Rêgo et al., 2008).

For reproductive analysis 617 individuals, 365 females and 252 males, were dissected. According to the analysis of variation in stages of gonadal maturation, it was found that mature females occur all year round, however the highest frequency is observed from January to June, with gradual decrease in frequency of mature females, which reached the lowest values in November. Semi-exhausted females are also present in almost all year round, except for February and March and the highest frequency of immature females was observed in the months of September and October (Figure 5).

The long reproductive period observed by temporal variation in gonadal maturation stages was corroborated by variation in gonadosomatic index of females $(\mathrm{H}=33.8$; $\mathrm{p}<0.001$ ), showing a similar pattern, with higher values observed from January to July and further decrease, with the lowest values occurring in November. We estimated that variation in river level was the variable with greater correlation with GSI of females (Spearman rho $=0.51$; $\mathrm{p}=0.09$ ), although it was not significant (Figure 6). Average temperature (Spearman rho $=-0.25 ; \mathrm{p}=0.43$ ) and rainfall (Spearman rho $=-0.08 ; \mathrm{p}=0.80$ ) showed no significant correlation with gonadosomatic index, with high values of GSI in both low and high levels of temperature and rainfall (Figure 6).

The estimated size at first maturation $\left(\mathrm{L}_{50}\right)$ was $20.2 \mathrm{~mm}$ for females, with a confidence interval ranging from 19.7 to $20.7 \mathrm{~mm}$, and the size at which all females reach sexual maturity $\left(\mathrm{L}_{100}\right)$ was $30.8 \mathrm{~mm}$ $(\mathrm{CI}=29.1$ to 33.5$)$ (Figure 7 ).

By counting oocytes of 50 females it was found that the average absolute fecundity for the population studied was

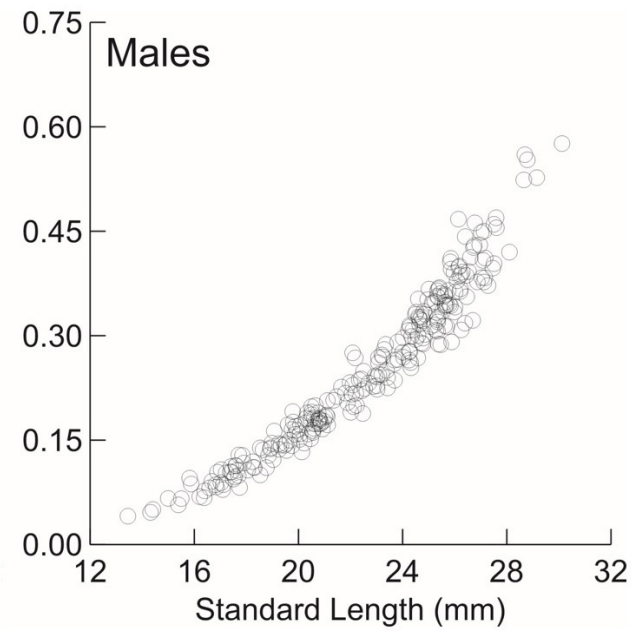

Figure 4. Weight/length relationship for H. eques females and males in Paraguay River from February 2009 to January 2011. 


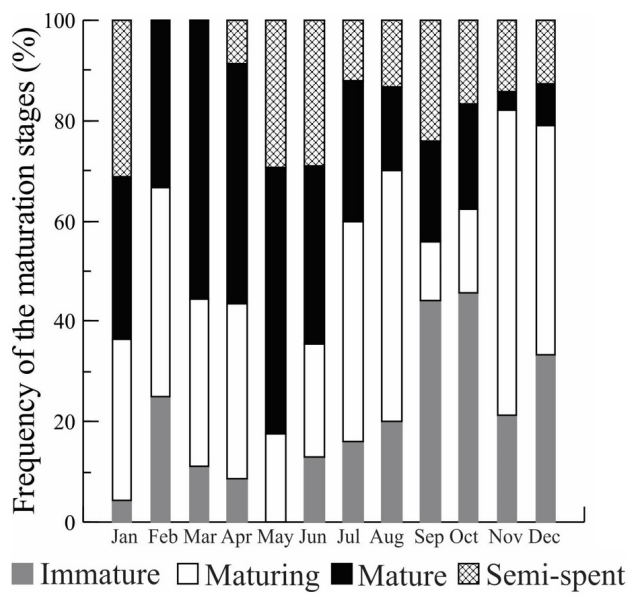

Figure 5. Temporal variation in the frequencies of maturation stages of $H$. eques females in Paraguay River from February/2009 to January/2011.

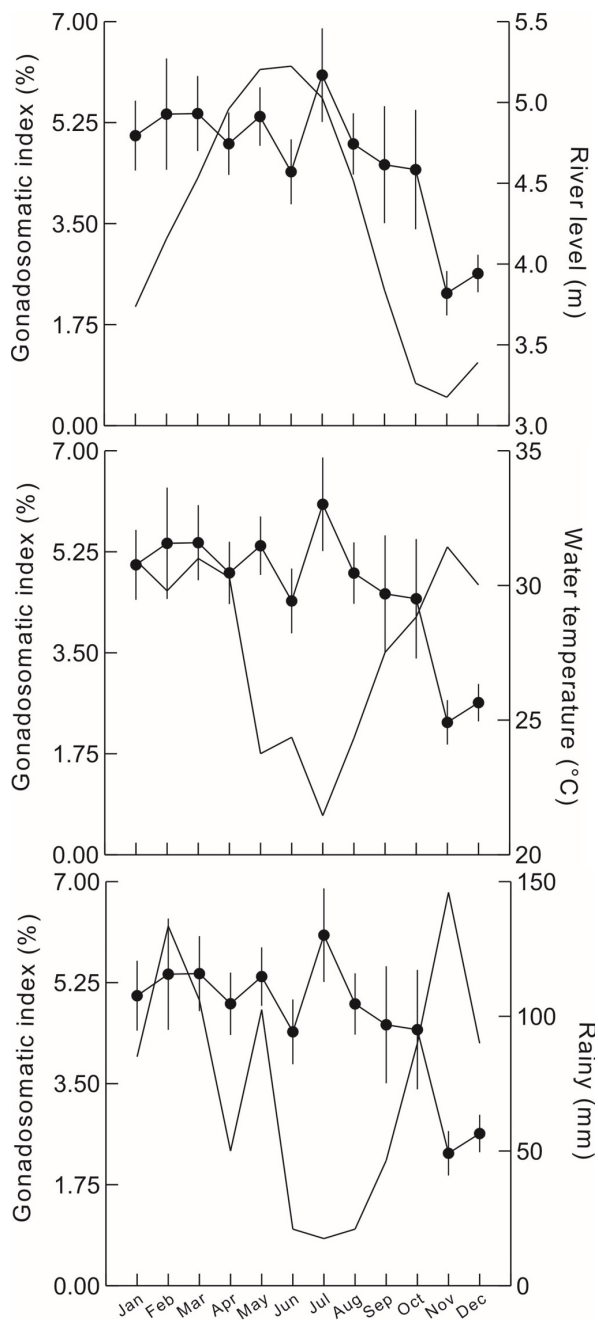

Figure 6. Temporal variation of gonadosomatic index for H. eques females and temperature, level of the Paraguay River and rainfall from February/2009 to January/2011.

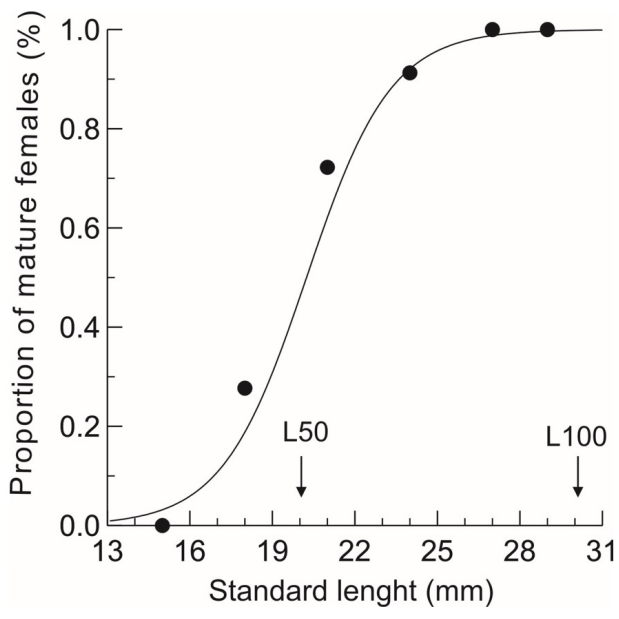

Figure 7. Relation between proportion of sexually mature females and standard length ( $\mathrm{mm})$ of $H$. eques in Paraguay River from February/2009 to January/2011.

191.9 oocytes/female, 67 minimum and 624 maximum, and the relative fecundity was estimated at 0.489 oocytes $/ \mathrm{mg}$. The absolute fecundity was positively correlated with total weight $(\mathrm{g})($ Spearman rho $=0.74 ; \mathrm{p}<0.001)$ and standard length (Spearman rho $=0.65 ; \mathrm{p}<0.001$ ) (Figure 8 ). The diameter of vitellogenic oocytes ranged between 0.05 and $0.82 \mathrm{~mm}$ with frequency distribution showing several modes, representing various stages of development, i.e., multiple spawning (Figure 9).

\section{Discussion}

The results obtained regarding structure in length of $H$. eques showed lower median length for both sexes in relation to what was found by Gonçalves et al. (2013) $($ Mean $/$ Females $=30 \mathrm{~mm}$; Mean $/$ Males $=29 \mathrm{~mm})$ in lentic environments in southeastern Brazil. The same authors reported a higher average length for $H$. eques females, explained by a reproductive strategy related to sexual dimorphism, which was not corroborated by our results, which can be justified by the fact that continuous reproductive activity decreases the somatic growth of individuals. Thus, our results are in agreement with the study by Assunção (2010) with Hyphessobrycon eques in lagoons of the Cuiabá River, North Pantanal, which reports standard lengths similar to the observed in southern Pantanal.

Moreover, it was observed a similar form of length and weight distribution between sexes, confirming the absence of sexual dimorphism and indicating that such a distribution pattern acts as a possible population balancing mechanism. Similar results, showing symmetrical distributions of length and weight and similar modal values of distribution between sexes were found by Abilhoa and Agostinho (2007) with Astyanax species and by Tondato et al. (2014) for Odontostilbe pequira (Steindachner 1882) in the same area sampled. 

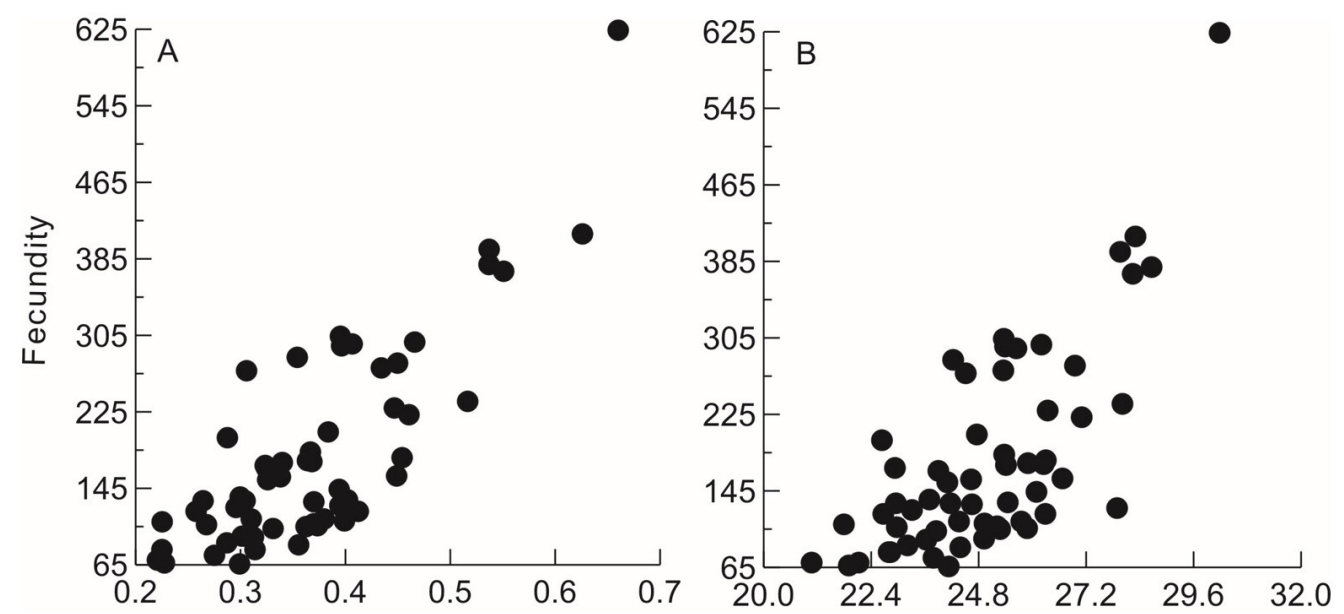

Figure 8. Fecundity relation of $H$. eques females in Paraguay River from February/2009 to January/2011 in function of (A) total weight (g) and (B) standard length.

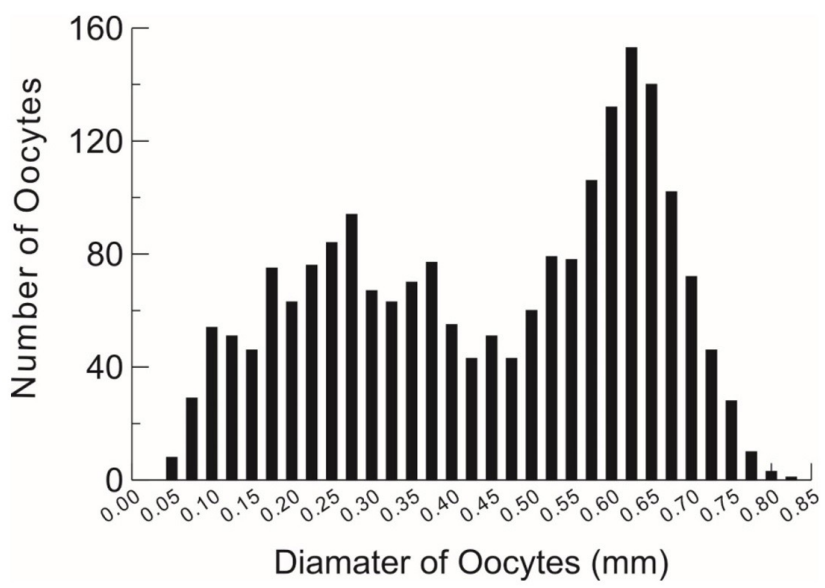

Figure 9. Frequency distribution of H. eques oocyte diameter in Paraguay River from February/2009 to January/2011.

According to Vicentini and Araújo (2003), sex ratio is basic information for the reproductive potential and for estimation of stock size, providing important data on the structure and dynamics of fish populations. In this study despite sex ratio differ significantly; there was no variation in sex ratio throughout the years, indicating that females are proportionally more numerous than males. Súarez et al. (2009, 2017) comment that larger proportion of females can be a strategy for rapid population growth, which would be important to $H$. eques which, due to its small size, never becomes large enough to no longer be prey, demanding a rapid population growth in order to minimize mortality and consequent probability of local extinction.

The length/weight relationship for $H$. eques indicated greater increment in weight in function of the similar length between males and females, contradicting the results observed by Gonçalves et al. (2013), which highlighted the negative allometric growth for the same species in lentic environments in southeastern Brazil, justified by a greater length reached by $H$. eques in this environment and by the statistic inverse correlation between maximum size reached by a population and its rate of weight increment (b of LWR).

In lentic environments, species tend to be less affected during reproduction due to low variability of environmental conditions (Bailly et al., 2008). Species that inhabit lotic environments are more susceptible to environmental variations (Angulo-Valencia et al., 2016). Generally, these species have different reproductive strategies, for example, the greater gain in weight than in length as indication of fat storage for gonadal development, which requires high energy expenditure (Rêgo et al., 2008; Mérona et al., 2009). Thus, the positive allometric growth of $H$. eques, suggests that the energy gained is directed toward investment in weight gain and not in growth, due to its continuous reproductive 
activity and other aspects such as high abundance of food (Souza et al., 2014).

Reproductive activity occurred practically throughout the year. However, reproductive investment was higher from January to June, when the river level was rising. Thus, despite the decrease in environmental temperature due to the beginning of autumn/winter, reproductive activity continued, suggesting that river level is a more important "reproductive trigger" than temperature and rainfall, as evidenced by Tondato et al. (2014). These authors reported a similar long reproductive pattern when analyzing the species $O$. pequira in the same region, in addition to highlighting the relation of reproduction with historical level of the river. A long reproductive period is common in small species (Hojo et al., 2004), but does not match with the reproductive strategy of seasonal environments (Vazzoler and Menezes, 1992), with short reproductive period associated with the favorable conditions of flood (Tedesco et al., 2008). Different from the results found in this study, in the Paraná River Basin, a short reproductive period was reported for $H$. eques, which showed reproductive period associated with period of rains (Gonçalves et al., 2013), showing the plasticity in reproductive strategies according to the local conditions.

However, a slow increase, characteristic of long-lasting floods, can result in prolonged spawning, because favorable conditions tend to persist (Bailly et al., 2008). Lourenço et al. (2008) observed that variations in water level are of great importance for population dynamics of two Characiformes species. Therefore, in the southern part of Brazilian Pantanal, due to high temperatures and flood are not coincident, it can also be beneficial for $H$. eques to spawn in low levels of water in the main channel of the river, when food resources are concentrated, as proposed by the hypothesis of "Low Flow Recruitment" (LFR) by Humphries et al. (1999).

Females of $H$. eques reach the first gonadal maturity with a similar length of $20.0 \mathrm{~mm}$ observed by Gonçalves et al. (2013) for the same species, suggesting a strong genetic influence even in different environmental conditions. In general, fish present intra-specific reproductive plasticity due to environmental conditions (Blanck and Lamouroux, 2007). However, it is known that the reproductive strategy of a species, among other traits, is the most conservative history of life (Agostinho et al., 1999), so that even in different environmental conditions, the species shows similar patterns in size at first maturation. It is important to note that, even with different average length between the population of $H$. eques analyzed here and the population observed by Gonçalves et al. (2013), the similar $\mathrm{L}_{50}$ suggests a high growth rate for the population in southern Pantanal as a possible adaptation to high mortality. According to Vazzoler (1996), the rapid reach to $L_{50}$ is an efficient mechanism to increase the genetic representation of the population in the next generation.

The absolute fecundity of $H$. eques was lower (191.9) in relation to fecundity (486) found for the same species in southeastern Brazil (Gonçalves et al. 2013), which was expected because species in lentic environments present high relative fecundity, characteristic of opportunistic species (Bailly et al., 2008). However, in the study by Gonçalves et al. (2013) H. eques presented total spawning with a reproductive period restricted to rainy season, as well as in the study by Assunção (2010) in the flood period of Northern Pantanal, while in this study partial spawning with long reproductive period was evidenced. Thus, in this study it was evident the higher reproductive investment, which corroborates the characteristics of females from lotic environments that tend to mature faster and have partial spawning as a strategy for species maintenance (Winemiller, 1989; Suzuki et al., 2005; Angulo-Valencia et al., 2016).

Moreover, the results indicate that fertility is related to total weight and standard length. This positive relation is usually attributed to a relation with more efficient energy accumulation by larger females, so, the more the female grows the more energy she has available to invest in reproduction, as evidenced by Barbieri et al. (2004). Complementarily, the higher mean sizes observed in southeastern Brazil also influence in mean fecundity of H. eques, thus, the differences in female's size and spawning type can explain the higher fecundity in southeastern Brazil when compared to Pantanal.

The spawning type is one of the reproductive traits modulated by environment that determine population survival (Winemiller, 1989). For H. eques the analysis suggests that spawning is partial, because it was noted a polimodal pattern in the distribution of oocytes diameter in mature females, as demonstrated in several small species (Hojo et al., 2004; Lourenço et al., 2008) and for Hyphessobrycon anisitsi (Eigenmann 1907) in southeastern Brazil (Gonçalves et al., 2013). However, Gonçalves et al. (2013) observed total spawning for $H$. eques, with restrict reproductive period and high fecundity, showing intraspecific variation according to the location. Associated with the spawning type, the diameter of oocytes observed in this study ( 0.5 to $0.8 \mathrm{~mm}$ ) was similar to the diameter $(0.6$ to $0.76 \mathrm{~mm})$ reported by Gonçalves et al. (2013) for H. eques. Therefore, H. eques population in southern Pantanal presents a long reproduction period with high reproductive investment spawning multiple batches throughout the years, as an attempt to compensate for lower fecundity.

Research that includes analyzes of reproductive traits is of utmost importance for the understanding of species autoecology and adaptations to the environment, besides contributing to studies of functional diversity, since reproductive traits can be components in these analyzes that include new measures of biodiversity (Cianciaruso et al., 2009).

According to the results, in Mato Grosso (H. eques), the increment in weight in function of equivalent length between sexes suggests that both are under the same environmental pressures, however, females reach greater size as a result of the need to accumulate larger amount of energy for reproduction. Moreover, the long reproductive investment independent of environmental factors, intensified by partial spawning, higher proportion of females and low $\mathrm{L}_{50}$, provides rapid population growth, a strategy necessary 
for survival of small species. Finally, the reproductive and population traits, with allocation of resources for reproduction of as many descendants as possible characterize $H$. eques as an r-strategist species.

\section{Acknowledgements}

The authors thank UEMS for logistic support; FUNDECT and CPP/MCT for financial support; W. Vicentin, M. M. Souza, M. J. Pereira, G. S. V. Duarte, F. S. Ferreira, and others who helped in field work. To CNPq for individual financial support to YRS (grant \#302794/2014-0). We also thank ICMBio for research permits (\#13.458-1).

\section{References}

ABILHOA, V. and AGOSTINHO, A.A., 2007. Aspectos biológicos de duas espécies de Astyanax (Teleostei, Characidae) em lagoas marginais do alto rio Iguaçu, Paraná, Brasil. Estudos de Biologia, vol. 29, pp. 23-32.

ADEBISI, A.A., 1987. The relationships between the fecundities, gonadosomatic indices and egg sizes of some fishes of Ogun River, Nigeria. Archiv für Hydrobiologie, vol. 111, pp. 151-156.

AGOSTINHO, A.A., GOMES, L.C., SUZUKI, H.I. and JÚLIOJUNIOR, H.F. 2003. Migratory fishes of the upper Paraná River basin, Brazil. In: J. Carolsfeld, B. Harvey, C. Ross, and A. Baer, eds. Migratory Fishes of South America: Biology, Fisheries and Conservation Status. Victoria: World Bank and IDRC, pp. 19-99.

AGOSTINHO,A.A., GOMES, L.C., VERÍSSIMO, S. and OKADA, E.K., 2004. Flood regime, dam regulation and fish in the Upper Parana River: effects on assemblage attributes, reproduction and recruitment. Reviews in Fish Biology and Fisheries, vol. 14, pp. 11-19. http://dx.doi.org/10.1007/s11160-004-3551-y.

AGOSTINHO, A.A., MIRANDA, L.E., BINI, L.M., GOMES, L.C., THOMAZ, S.M. and SUZUKI, H.I. 1999. Patterns of colonization in neotropical reservoir, and prognoses on aging. In: J.G. Tundisi, and M. Strasbaka, eds. Theoretical Reservoir Ecology and Its Applications. São Carlos: Brazilian Academic of Science and Backhuy, pp. 227-265.

ALMEIDA-SILVA, P.H. and MAZZONI, R., 2014. Life history aspects of Phalloceros anisophallos Lucinda, 2008 (Osteichthyes, Poeciliidae) from Córrego Andorinha, Ilha Grande (RJ, Brazil). Studies on Neotropical Fauna and Environment, vol. 49, no. 3, pp. 191-198. http://dx.doi.org/10.1080/01650521.2014.957968.

ANGULO-VALENCIA, M.A., AGOSTINHO, A.A., SUZUKI, H.I., LUZ-AGOSTINHO, K.D.G. and AGOSTINHO, C.S., 2016. Impoundments affect fish reproduction regardless of reproductive strategy. Lakes and Reservoirs: Research and Management, vol. 21, no. 4, pp. 362-374. http://dx.doi.org/10.1111/lre.12151.

ARANTES, F.P., SANTOS, H.B., RIZZO, E. and SATO, Y., 2011. Collapse of the reproductive process of two migratory fish (Prochilodus argenteus and Prochilodus costatus) in the Três Marias Reservoir, São Francisco River, Brazil. Journal of Applied Ichthyology, vol. 27, no. 3, pp. 847-853. http://dx.doi.org/10.1111/j.1439-0426.2010.01583.x.

ASSUNÇÃO, W.R.C., 2010. Estrutura populational, período reprodutivo e alimentação do Mato grosso, Hyphessobrycon eques Steindachner, 1882 (Pisces: Characiformes) em lagoas marginais do rio Cuiabá, Pantanal norte. Cuiabá: Universidade Federal de Mato Grosso, 37 p. Dissertação de Mestrado em Ecologia e Conservação da Biodiversidade.

BAILLY, D., AGOSTINHO,A.A. and SUZUKI, H.I., 2008. Influence of the flood regime on the reproduction of fish species with different reproductive strategies in the Cuiabá River, Upper Pantanal, Brazil. River Research and Applications, vol. 24, no. 9, pp. 1218-1229. http://dx.doi.org/10.1002/rra.1147.

BARBIERI, G., SALLES, F.A., CESTAROLLI, M.A. and TEIXEIRAFILHO, A.R., 2004. Estratégias reprodutivas do dourado, Salminus maxillosus e do curimbatá, Prochilodus lineatus no Rio Mogi Guaçu, Estado de São Paulo, com ênfase nos parâmetros matemáticos da dinâmica populacional. Acta Scientiarum. Biological Sciences, vol. 26, no. 2, pp. 169-174. http://dx.doi.org/10.4025/actascibiolsci.v26i2.1631.

BLANCK, A. and LAMOUROUX, N., 2007. Large-scale intraspecific variation in life-history traits of European freswater fish. Journal of Biogeography, vol. 34, no. 5, pp. 862-875. http://dx.doi.org/10.1111/ j.1365-2699.2006.01654.x.

BUCKUP, P.A., MENEZES, N.A. and GHAZZI, M.S., 2007. Catálogo das espécies de peixes de água doce do Brasil. Rio de Janeiro: Museu Nacional, $195 \mathrm{p}$.

CIANCIARUSO, M.V., SILVA, I.A. and BATALHA, M.A., 2009. Phylogenetic and functional diversities: new approaches to community Ecology. Biota Neotropica, vol. 9, no. 3, pp. 93-103. http://dx.doi. org/10.1590/S1676-06032009000300008.

CUNHA, N.L., CATELLA, A.C. and KINAS, M.A., 2007. Growth parameters estimates for a small fish of the Pantanal, Brazil: Moenkhausia dichroura (Characiformes; Characidae). Brazilian Journal of Biology $=$ Revista Brasileira de Biologia, vol. 67, no. 2, pp. 293-297. http://dx.doi.org/10.1590/S1519-69842007000200014. PMid:17876439.

DAGOSTA, F.C.P., MARINHO, M.M.F., CAMELIER, P. and LIMA, F.C.T., 2016. A new species of Hyphessobrycon (Characiformes: Characidae) from the Upper Rio Juruena Basin, Central Brazil, with a redescription of H. cyanotaenia. Copeia, vol. 104, no. 1, pp. 250-259. http://dx.doi.org/10.1643/CI-15-243.

FANTIN-CRUZ, I., PEDROLLO, O., CASTRO, N.M.R., GIRARD, P., ZEILHOFER, P. and HAMILTON, S.K., 2011. Historical reconstruction of floodplain inundation in the Pantanal (Brazil) using neural networks. Journal of Hydrology, vol. 399, no. 3-4, pp. 376-384. http://dx.doi.org/10.1016/j.jhydrol.2011.01.014.

FROESE, R. and PAULY, D. 2011 [viewed 23 February 2017]. FishBase [online]. Available from: www.fishbase.org

GONÇALVES, C.S., SOUZA, U.P., FERREIRA, F.C., PERESSIN, A. and BRAGA, F.M.S., 2013. Life-history strategies associated to reproduction of three Hyphessobrycon species (Characidae) in lentic environments of upper Paraná River basin. Acta Limnologica Brasiliensia, vol. 25, no. 4, pp. 398-405. http://dx.doi.org/10.1590/ S2179-975X2013000400005.

HOJO, R.E.S., SANTOS, G.B. and BAZZOLI, N., 2004. Reproductive biology of Moenkhausia intermedia (Eigenmann) (Pisces, Characiformes) in Itumbiara Reservoir, Goiás, Brazil. Revista Brasileira de Zoologia, vol. 21, no. 3, pp. 519-524. http:// dx.doi.org/10.1590/S0101-81752004000300015.

HUMPHRIES, P., KING, A.J. and KOEHN, J.D., 1999. Fish, flows and flood plains: links between freshwater fishes and their environment in the Murray-Darling River system, Australia. Environmental Biology of Fishes, vol. 56, no. 1/2, pp. 129-151. http://dx.doi.org/10.1023/A:1007536009916.

JONES, R.E., PETRELL, R.J. and PAULY, D., 1999. Using modified length-weight relationships to assess the condition of fish. Aquacultural Engineering, vol. 20, no. 4, pp. 261-276. http://dx.doi.org/10.1016/ S0144-8609(99)00020-5.

LOURENÇO, L.S., FERNANDES, I.M. and SÚAREZ, Y.R., 2012. Spatial and temporal variation in population structure of Hemigrammus marginatus (Characiformes: Characidae) in streams of the Ivinhema 
River Basin, Brazil. Zoologia, vol. 29, no. 4, pp. 300-307. http:// dx.doi.org/10.1590/S1984-46702012000400003.

LOURENÇO, L.S., MATEUS, L.A.F. and MACHADO, N.G., 2008. Sincronia na reprodução de Moenkhausia sanctaefilomenae (Steindachner) (Characiformes: Characidae) na planície de inundação do rio Cuiabá, Pantanal Mato-Grossense, Brasil. Revista Brasileira de Zoologia, vol. 25, no. 1, pp. 20-27. http://dx.doi.org/10.1590/ S0101-81752008000100004.

MATEUS, L.A.F. and PENHA, J.M.F., 2007. Dinâmica populacional de quatro espécies de grandes bagres na bacia do rio Cuiabá, Pantanal norte, Brasil (Siluriformes, Pimelodidae). Revista Brasileira de Zoologia, vol. 24, no. 1, pp. 87-98. http://dx.doi.org/10.1590/S010181752007000100012 .

MÉRONA, B., MOL, J., VIGOUROUX, R. and CHAVES, P.T., 2009. Phenotypic plasticity in fish life-history traits in two neotropical reservoirs: Petit-Saut Reservoir in French Guiana and Brokopondo Reservoir in Suriname. Neotropical Ichthyology, vol. 7, no. 4, pp. 683-692. http://dx.doi.org/10.1590/S1679-62252009000400018.

MÔNACO, I.A., SÚAREZ, Y.R. and LIMA-JUNIOR, S.E., 2014. Influence of environmental integrity on feeding, condition and reproduction of Phalloceros harpagos Lucinda, 2008 in the Tarumã stream micro-basin. Acta Scientiarum. Biological Sciences, vol. 36, no. 2, pp. 181-188. http://dx.doi.org/10.4025/actascibiolsci.v36i2.21394.

NORMANDO, F.T., SANTIAGO, K.B., GOMES, M.V.T., RIZZO, E. and BAZZOLI, N., 2014. Impact of the Três Marias dam on the reproduction of the forage fish Astyanax bimaculatus and A. fasciatus from the São Francisco River, downstream from the dam, southeastern Brazil. Environmental Biology of Fishes, vol. 97, no. 3, pp. 309-319. http://dx.doi.org/10.1007/s10641-013-0153-3.

OLDEN, J.D. and KENNARD, M.J. 2010. Intercontinental comparison of fish life-history strategies along a gradient of hydrologic variability. In: K.B. GIDO, and D. A. JACKSON, eds. Community ecology of stream fishes: concepts, approaches, and techniques. Bethesda: American Fisheries Society Symposium, vol. 73, pp. 83-107.

PASCHOALINI, A.L., PERINI, V.R., RIBEIRO, D.M., FORMAGIO, P.S., RIZZO, E. and BAZZOLI, N., 2013. Reproduction of Pimelodus maculatus (Siluriformes: Pimelodidae) in three section of Grande River basin, downstream Porto Colombia dam, south-eastern Brazil. Neotropical Ichthyology, vol. 11, no. 3, pp. 615-623. http://dx.doi. org/10.1590/S1679-62252013000300015.

PELICICE, F.M. and AGOSTINHO, A.A., 2006. Feeding ecology of fishes associated with Egeria spp. patches in a tropical reservoir, Brazil. Ecology Freshwater Fish, vol. 15, no. 1, pp. 10-19. http:// dx.doi.org/10.1111/j.1600-0633.2005.00121.x.

RÊGO, A.C.L., PINESE, O.P., MAGALHÃES, P.A. and PINESE, J.F., 2008. Relação peso-comprimento para Prochilodus lincatus (Valenciennes, 1836) e Leporinus friderici (Bloch, 1794) (Characiformes) no reservatório de Nova Ponte - EDPA de Galheiro, rio Araguari, MG. Revista Brasileira de Zoociências, vol. 10, pp. 13-21.

ROA, R., ERNST, B. and TAPIA, F., 1999. Estimation of size at sexual maturity: an evaluation of analytical and resampling procedures. Fish Bulletin, vol. 97, pp. 570-580.

SILVA, J.S.V. and ABDON, M.M., 1998. Delimitação do Pantanal Brasileiro e suas sub-regiões. Pesquisa Agropecuária Brasileira, vol. 33, pp. 1703-1711. Número Especial.

SOUZA, U.P., FERREIRA, F.C. and BRAGA, F.M.S. and WINEMILLER, K.O., 2014. Feeding, body condition and reproductive investment of Astyanax intermedius (Characiformes, Characidae) in relation to rainfall and temperature in a Brazilian Atlantic Forest stream. Ecology Freshwater Fish, vol. 24, no. 1, pp. 123-132. http:// dx.doi.org/10.1111/eff.12131.
SÚAREZ, Y.R., SILVA, E.A. and VIANA, L.F., 2017. Reproductive biology of Astyanax lacustris (Characiformes: Characidae) in the southern Pantanal floodplain, upper Paraguay River basin, Brazil. Environmental Biology of Fishes, vol. 100, no. 7, pp. 775-783. http:// dx.doi.org/10.1007/s10641-017-0604-3.

SÚAREZ, Y.R., SILVA, J.P., VASCONCELOS, L.P. and ANTONIALLI-JÚNIOR, W.F., 2009. Ecology of Phallotorynus pankalos (Cyprinodontiformes: Poeciliidae) in a first-order stream of the upper Paraná Basin. Neotropical Ichthyology, vol. 7, no. 1, pp. 49-54. http://dx.doi.org/10.1590/S1679-62252009000100007.

SUZUKI, H.I., BULLA, C.K., AGOSTINHO, A.A. and GOMES, L.C., 2005. Estratégias reprodutivas de assembleias de peixes em reservatórios. In: L. Rodrigues, S.M. Agostinho and L.C. Gomes, eds. Biocenoses em Reservatório: Padrões Espaciais e Temporais. São Carlos: RiMa, pp. 223-242.

TEDESCO, P.A., HUGUENY, B., OBERDORFF, T., DÜRR, H.H., MÉRIGOUX, S. and DE MÉRONA, B., 2008. River hydrological seasonality influences life history strategies of tropical riverine fishes. Oecologia, vol. 156, no. 3, pp. 691-702. http://dx.doi.org/10.1007/ s00442-008-1021-2. PMid:18368426.

TONDATO, K.K., FIALHO, C.B. and SÚAREZ, Y.R., 2012. Life history traits of Odontostilbe pequira (Steindachner, 1882) in the Pantanal of Porto Murtinho, Mato Grosso do Sul, State, Brazil. Oecologia Australis, vol. 16, no. 4, pp. 878-890. http://dx.doi. org/10.4257/oeco.2012.1604.11.

TONDATO, K.K., FIALHO, C.B. and SÚAREZ, Y.R., 2014. Reproductive ecology of Odontostilbe pequira (Steindachner, 1882) (Characidae, Cheirodontinae) in the Paraguay River, southern Pantanal, Brazil. Environmental Biology of Fishes, vol. 97, no. 1, pp. 13-25. http://dx.doi.org/10.1007/s10641-013-0119-5.

VAZZOLER, A.E.A.M. 1996. Biologia da reprodução de peixes teleósteos: teoria e prática. Maringá: Editora Universidade Estadual de Maringá, 169 p.

VAZZOLER, A.E.A.M. and MENEZES, N.A., 1992. Síntese dos conhecimentos sobre o comportamento reprodutivo dos Characiformes da América do Sul (Teleostei, Ostariophysi). Brazilian Journal of Biology $=$ Revista Brasileira de Biologia, vol. 52, pp. 626-640.

VICENTINI, R.N. and ARAÚJO, F.G., 2003. Sex ratio and size structure of Micropogonias furnieri (Desmarest, 1823) (Perciformes, Sciaenidae) in Sepetiba Bay, Rio de Janeiro, Brazil. Brazilian Journal of Biology = Revista Brasileira de Biologia, vol. 63, no. 4, pp. 559-566. http://dx.doi.org/10.1590/S1519-69842003000400003. PMid:15029367.

WINEMILLER, K.O. 2003. Life history strategies of fishes. In: G. C. Ray, and G. Ray, eds. Coastal Realm Conservation: Science and Policy. Oxford: McCormick, Blackwell Scientific, pp. 106-107.

WINEMILLER, K.O., 1989. Patterns of variation in life history among South American fishes in seasonal environments. Oecologia, vol. 81, no. 2, pp. 225-241. http://dx.doi.org/10.1007/BF00379810. PMid:28312542.

WOOTTON, R. 1999. Ecology of Teleost fishes. 2nd ed. London: Chapman \& Hall, $416 \mathrm{p}$.

ZEUG, S.C. and WINEMILLER, K.O., 2008. Relationships between hydrology, spatial heterogeneity, and fish recruitment dynamics in a temperate floodplain river. River Research and Applications, vol. 24, no. 1, pp. 90-102. http://dx.doi.org/10.1002/rra.1061. 